\title{
MINERAL RESOURCE POTENTIAL OF THE EAGLE ROCK ROADLESS AREA, SNOHOMISH AND KING COUNTIES, WASHINGTON
}

\author{
By \\ S. E. Church and R. W. Tabor, U.S. Geological Survey, \\ and \\ F. L. Johnson, U.S. Bureau of Mines
}

\section{STUDIES RELATED TO WILDERNESS}

Under the provisions of the Wilderness Act (Public Law 88-577, September 3, 1964) and related acts, the U.S. Geological Survey and the U.S Bureau of Mines have been conducting mineral surveys of wilderness and primitive areas. Areas officially designated as "wilderness," "wild," or "canoe" when the acts were passed were incorporated into the National Wilderness Preservation System, and some of them are currently being studied. The act provided that areas under consideration for wilderness designation should be studied for suitability for incorporation into the Wilderness System. The mineral surveys constitute one aspect of the suitability studies. The act directs that the results of such surveys are to be made available to the public and submitted to the President and the Congress. This report discusses the results of a mineral survey of the Eagle Rock Roadless Area (06054) in the Mount Baker-Snoqualmie National Forest, Snohomish and King Counties, Wash. The Eagle Rock Roadless Area was classified as a further planning area during the Second Roadless Area Review and Evaluation (RARE II) by the U.S. Forest Service, January 1979.

\section{MINERAL RESOURCE POTENTIAL SUMMARY STATEMENT}

A multidisciplinary team of geoscientists from the U. S. Geological Survey and the U.S. Bureau of Mines has evaluated the mineral potential of the Eagle Rock Roadless Area. The Sunset mine, the second largest producer of copper in the State of Washington, has 307,500 tons of indicated and inferred resources averaging 3.46 percent copper. The mine portal is outside the Eagle Rock Roadless Area, in a re-entrant of the roadless area boundary along Trout Creek. However, diamond drilling from the second level in the mine intersected two favorable lode zones of mineralization south of the mine portal within the roadless area. Thirteen additional prospects within the roadless area contain copper- and commonly silver-bearing zones ranging in grade from 0.20 to 5.72 percent copper and as much as 4.2 oz silver per ton. However, the vast majority of the occurrences average less than 0.5 percent copper and less than $1.0 \mathrm{oz}$ silver per ton. Mineralization is localized along steeply dipping shears in a regional tensional joint system (Grant, 1969) and lode deposits have been formed by a hydrothermal vein-filling process (Weaver, 1912). Because of the mineralogic zonation of metals within the veins and the potassic alteration associated with copper ores, we interpret the vein deposits to be a porphyry-copper system emplaced in competent rocks having a widely-spaced joint pattern. This model has important ramifications in evaluating the mineral resources of the area because the irregular spacing of fractures in competent rock units may preclude the formation of large-tonnage disseminated deposits. The copper-bearing occurrences found in the roadless area between Trout Creek and Bitter Creek may be indicative of a larger deposit at depth. Detailed mapping of structural patterns and altered zones is required to delineate the zones of greatest mineralization. Within the roadless area, all of the outcrop area of the Index batholith and part of the metamorphic volcanic and sedimentary septum have a moderate potential for the occurrence of copper and silver resources in hydrothermal veins. The remaining area of the septum has a moderate but less favorable potential for copper and silver resources. The significance of widespread geochemical anomalies in the Grotto batholith remains an enigma in spite of extensive field sampling of sheared and oxidized zones. A low potential for base- and precious-metal resources is indicated for the Grotto batholith in the Eagle Rock Roadless Area.

\section{INTRODUCTION}

The Eagle Rock Roadless Area covering about 33,100 acres of National Forest land and containing about 1,000 acres of privately owned land, is approximately $45 \mathrm{mi}$ east-northeast of Seattle, Wash. (fig. 1). It is bounded on the north and northwest by the North Fork of the Skykomish River, on the southwest by the South Fork of the Skykomish River, and on the east by the Beckler River. Access to the southwest boundary is from U.S. Highway 2; access to the northwest and east boundaries is by county and U.S. Forest Service roads. 


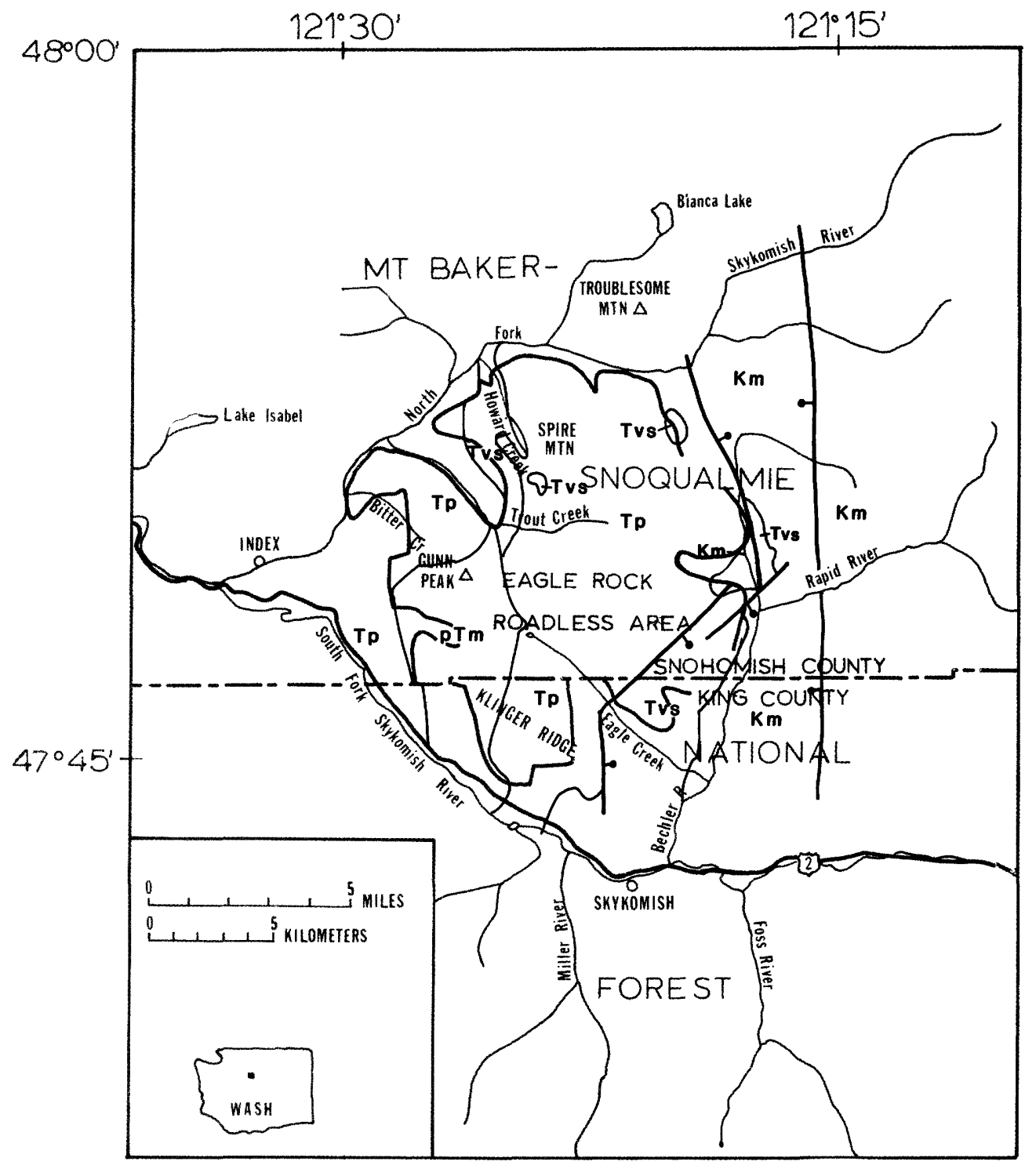

EXPLANATION

- APPROXIMATE BQUNDARY OF THE EAGLE ROCK ROADLESS AREA (06054)

- GEOLOGIC CONTACT

T FAULT--Ball and bar on downthrown side

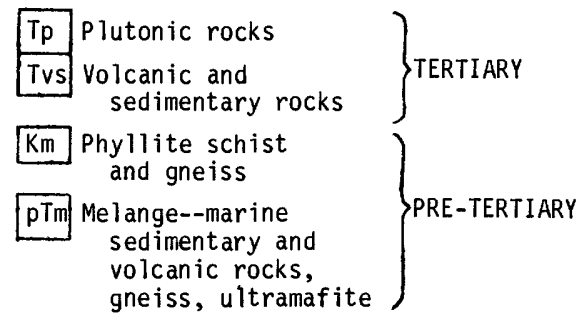

Figure 1.--Index map and simplified geologic map of the Eagle
Rock Roadless Area, 06054 (geology after Tabor and others,
$1982 b$ ). 
The area is characterized by extremely rough topography. Elevations range from $530 \mathrm{ft}$ at Index to $6,240 \mathrm{ft}$ at the summit of Gunn Peak. Located on the west side of the Cascade crest, the roadless area receives heavy precipitation. Very dense brush and forest cover the area from valley floors to about 5,000 ft elevation.

\section{Present and Previous Studies}

This report summarizes studies by the U.S. Geological Survey and the U.S. Bureau of Mines, and is designed to evaluate the mineral potential of the Eagle Rock Roadless Area. Investigations by the U.S. Geological Survey included geologic mapping (Tabor and others, 1982b), geochemical reconnaissance (Church and others, in press), and aeromagnetic interpretation (Flanigan and others, in press) conducted from 1978-1982. Detailed investigations by the U.S. Bureau of Mines of the mining activity and production, and field studies of mines and prospects were made during the 1979-1981 field seasons (Johnson and others, 1983). The roadless area includes a major portion of the Index mining district first described by Weaver (1912).

We examined forty-two underground and five surface mine workings, and collected and analyzed samples from the mine workings, stockpiles, and dumps to define ore suites and to determine ore grades. We also briefly studied the terrain in drainages having geochemical anomalies and sampled altered zones identified during the geologic mapping. Previous studies of specific mines in the Index district have been particularly useful. The U.S. Bureau of Mines examined the Sunset mine in 1942 and drilled 14 holes during a 1950 exploration program. Thirty-seven more exploratory holes were drilled under a Defense Minerals Exploration Administration (DMEA) contract in 1955. The U.S. Bureau of Mines examined the Merchant mine in 1946 and again in 1950, and the NonPareil mine in 1957. The Sunset and Non-Pareil mines are just outside the roadless area boundary.

Some exploration by private companies has been conducted in the Eagle Rock Roadless Area. During the summer of 1980, Bethex Corporation explored for minerals in the Trout Creek drainage.

\section{ACKNOWLEDGMENTS}

Collection of field samples was expedited by the skill of our helicopter pilots, Anthony Reece, Doug Bucklew, Leroy Brown, Ben VanEtten, Tim Wiltrout, Jerry Wise, and the late Jack Johnson. We thank Derek Booth, Paul Carroll, Brett Cox, Virgil Frizzell Jr., M. Jean Heatherington, Sam Johnson, Kathy Lombardo, Joe Marquez, Elizabeth L. Mathieson, Jim Talpey, and John Whetten for their assistance in collecting geological and geochemical samples. We thank James G. Frisken, William M. Kemp and R. Scott Werschky for their assistance in examining mineralized structures. We also wish to thank David B. Denton, Robin B. McCulloch, and Scott A. Stebbins for their assistance in the sampling and evaluation of mines and prospects. Field investigations of the mines and prospects were aided by Frank Federspiel, Rod Jeske, Eric Cather, Mike DeVeau, Jim Werle, Jim Greeves, Larry Reigel, Sue Lupenski, Rob Collins, Steve Drussel, Craig Rankin, Stuart Simpson, Corolla
Hoag, Susan Douglas, Ruth Satterlund, Dave Hatfield, and Rick Fredricksen.

\section{GEOLOGY, GEOCHEMISTRY, AND GEOPHYSICS PERTAINING TO MINERAL RESOURCE ASSESSMENT}

Geology

Rocks of the Eagle Rock Roadless Area range in age from Permian to Miocene. The oldest rocks, shown on the geologic map as a pre-Tertiary melange (fig. 1), are highly deformed, pervasively sheared, faulted, and variably metamorphosed marine sedimentary and volcanic rocks including limestone, ribbon chert, graywacke, shale, and basalt of the Gunn Peak and Barclay Creek Formations of Yeats (1964). Marble pods within the unit exposed south of the roadless area contain fusulinids of Permian age (Danner, 1966, p. 363). Tectonically overlying the marine rocks or imbricated with them is migmatitic gneiss (Yeats, 1964) of probable Triassic age (Whetten and others, 1980). Because of the extreme deformation and range in ages of its constituents, Tabor and others (1982a; also Frizzell and others 1982) consider the gneiss and marine rocks to be part of a melange. In the southwestern part of the roadless area, the melange is preserved as a thick septum between two Tertiary plutons (see fig. 1) and has been thermally metamorphosed, locally to pyroxene hornfels.

Unconformably overlying the pre-Tertiary melange unit and also forming a thin septum between the Tertiary plutons is the Eocene Swauk Formation (a part of unit Tvs on fig. 1) a fluviatile, feldspathic sandstone. Thermal metamorphism has obscurred structures in the Swauk Formation, but the unit has been traced northwestward across the North Fork of the Skykomish River into the Silver Creek district (Tabor and others, 1982b) where it is overlain by Eocene volcanic rocks. The rhyolitic Eagle Tuff of Yeats (1977), a Miocene volcanic unit, is preserved in a down-faulted block in the southeastern part of the roadless area. The tuff unconformably overlies the Swauk Formation and on figure 1 is also included in the Eocene supracrustal units (Tvs). The tuff is not strongly deformed or thermally metamophosed; original bedding structures, flattened pumice fragments, and glassy shards are preserved.

Bordering the Eagle Rock Roadless Area to the east and separated from the plutonic rocks by faults is a downdropped block of phyllite, schist and gneiss, metamorphosed during Cretaceous time. This unit (shown as $\mathrm{Km}$ on fig. 1) includes the Tonga Formation of Yeats (1958a), a metapelite and metasandstone that varies in metamorphic grade from black phyllite and greenschist to graphitic-staurolite-garnet-biotite schist (Tabor and others, 1982b); Yeats (1958a, p. 41) describes blue amphibole schists which are locally intercalated in the phyllite.

Two intrusive batholiths crop out in the Eagle Rock Roadless Area. The Index batholith of quartz diorite, tonalite, and granodiorite crops out on the west side of the septum of pre-Tertiary to Eocene rocks and extends north and west of the roadless area (Tabor and others, 1982a). Radiometric potassiumargon determinations on hornblende and biotite from the Index batholith give concordant ages of about 


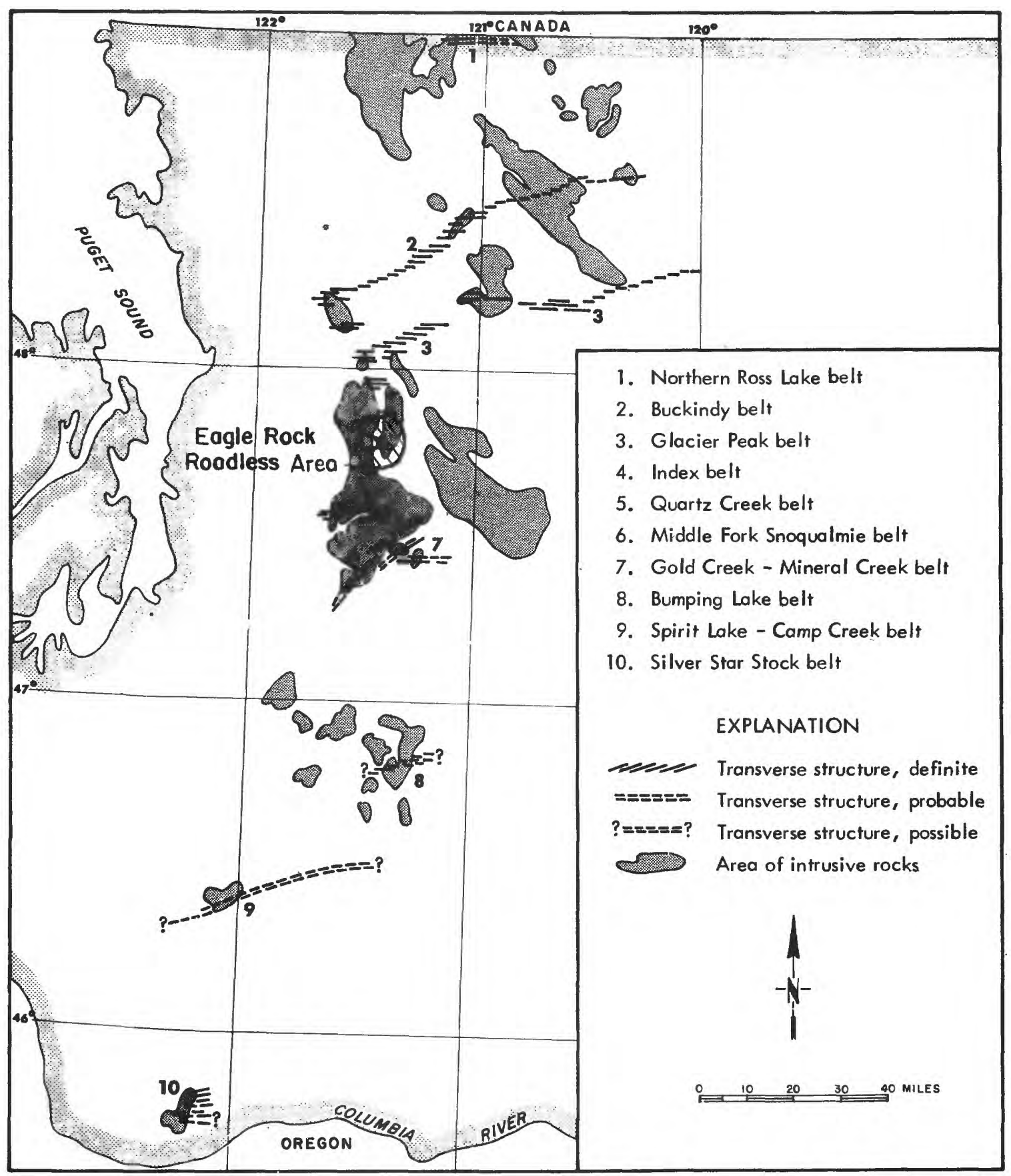

Figure 2.--Map of the known and suspected transverse structural
belts in the Cascade Range, northern Washington (after
Grant, 1969 , p. 40 ). 
$33 \mathrm{~m} . \mathrm{y}$. (data summarized by Tabor and others, 1982b). In contrast to the relatively uniform Index batholith, the Grotto batholith is more varied in composition, ranging from granite to quartz gabbro. Northeast of the roadless area, granite in the San Juan Creek area may be a late stage differentiate of the Grotto batholith; the biotite granite is characterized by granophyric porphyry with graphic intergrowths of quartz and orthoclase. Potassium-argon determinations on hornblende and biotite in the Grotto batholith yield concordant ages of about $25 \mathrm{~m}$.y. (data summarized by Tabor and others $1982 \mathrm{~b}$ ), an age equivalent to that of the early phase of the Snoqualmie batholith south of the roadless area. The Eagle Tuff of Yeats (1977), which has been dated by the fission-track method using zircons (Vance and Naeser, 1977), has an age of about $23 \mathrm{~m} \cdot \mathrm{y}$. and may be an extrusive equivalent of the Grotto batholith.

The roadless area at one time was bisected by the north-trending Straight Creek fault, a major Pacific Northwest right-lateral strike-slip fault (Misch 1977; Vance and Miller, 1981). The fault has been intruded by the Grotto batholith and in the roadless area that body now separates the melange unit on the west (shown as pTm in fig. 1) from the higher-grade metamorphic rocks to the east (shown as $\mathrm{Km}$ on fig. 1). North-northwest-trending normal faults in what could be called the Straight Creek fault zone, juxtaposed the plutonic terrane of the Eagle Rock Roadless Area with the volcanic and metamorphic terranes to the south and east.

Studies of the orientation of hydrothermal veins within the Index batholith (Weaver, 1912, p. 50-51) indicate a set of conjugate tensional shears. The predominant strike is $\mathrm{N} .75^{\circ} \mathrm{W}$. in the eastern part of the Index batholith and $\mathrm{N} .45^{\circ} \mathrm{E}$. in the western part. Grant (1969, p. 79) notes that of the 19 major mineralized vein systems studied by Weaver (1912), thirteen strike northeast whereas the remaining strike northwest. Grant (1969, p. 34-46), in a structural analysis of the mineralization within the Cascade Range, showed that mineralization is localized along and controlled by regional, transverse structures trending generally northeast (see fig. 2). The Index belt parallels the more prominent Glacier Peak belt which Grant (1969) defines as the locus of several major areas of mineralization. The hydrothermal vein system, which cuts the Index batholith and adjacent country rocks in the Bitter Creek-Trout Creek area, does not appear to extend into tine Grotto batholith, indicating the Grotto batholith postdates the hydrothermal system.

\section{Geochemistry}

We divided geochemical investigations of the roadless area into three parts, each having a specific objective: (1) bedrock geochemistry, (2) streamsediment geochemistry, and (3) analysis and investigation of altered areas indicated by geologic studies, mining activity, and geochemical reconnaissance of drainage basins. Analytical results from the bedrock geochemical studies (Church and others, 1983) define the background and threshold values for the rock units. Church and others (in press) present a geologic interpretation of the geochemical reconnaissance studies of the Eagle Rock Roadless Area.
We collected 80 stream-sediment samples from the roadless area in conjunction with the geologic mapping. Sampled stream basins had areas as large as $3 \mathrm{mi}^{2}$. In addition, we collected 15 pannedconcentrate samples from stream sediments from larger, second-order drainage basins for analysis of the nonmagnetic, heavy-mineral fraction. All analytical results (Church and others, 1982) were obtained using direct-current arc emission spectrography.

Widespread geochemical anomalies occur in drainages underlain by the Index and Grotto batholiths. In addition the Index and Grotto batholiths have distinctive elemental suites. The Index batholith is characterized by anomalous concentrations of cobalt, copper, molybdenum, tungsten, lead, and silver with one drainage basin each having anomalous concentrations of zinc and barium. In contrast, the Grotto batholith is characterized by anomalous concentrations of cobalt, copper, molybdenum, tungsten, tin, gold, bismuth, lead, and silver, with one drainage basin having an anomalous concentration of barium (Church and others, in press). The anomalous elemental suite from the Index batholith is typical of geochemical suites generally associated with porphyry-copper systems found in the Canadian cordillera (Pilcher and McDougall, 1976, p. 79-84), whereas the suite associated with the Grotto batholith is the same as the suite associated with the hydrothermal vein systems of the Monte Cristo and Silver Creek districts to the north across the North Fork of the Skykomish River (Church and others, in press). Paralleling the geochemical differences are distinctions in the ores of the two districts that may reflect the respective batholith sources. Arsenic and antimony are abundant in the ores of the Monte Cristo district (Spurr, 1901). In contrast, arsenic and antimony are present at low concentrations in ores from the Index district (tables 9 and 10; Church and others 1983) although there is a small amount of arsenic in ores from the Merchant mine (no. 38 on fig. 3 ) and the Atlantic claim (no. 32 on fig. 3 ).

\section{Geophysics}

Aeromagnetic data from the roadless area were examined in conjunction with a geophysical study of the Glacier Peak Wilderness (Flanigan and others, in press). The data were compiled from several aeromagnetic surveys; flight directions for the aeromagnetic surveys were generally northeastsouthwest, transverse to the regional structure. Flight lines were drape-flown at an elevation of $1000 \mathrm{ft}$ with $0.5 \mathrm{mi}$ spacing. Topographic anomalies are inherent in the data due to imperfect draping in the steep terrain. The magnetic character of the Eagle Rock terrain exhibits a highly complex pattern characteristic of volcanic terranes. No diagnostic magnetic signature could be discerned when compared with the distribution of known deposits in the Index mining district.

\section{MINING DISTRICTS AND MINERALIZATION}

The Index mining district, centered around Index, Wash., extends into the western part of the roadless area. Mining claims were first located in the early 1890 's, with the first major production coming from 


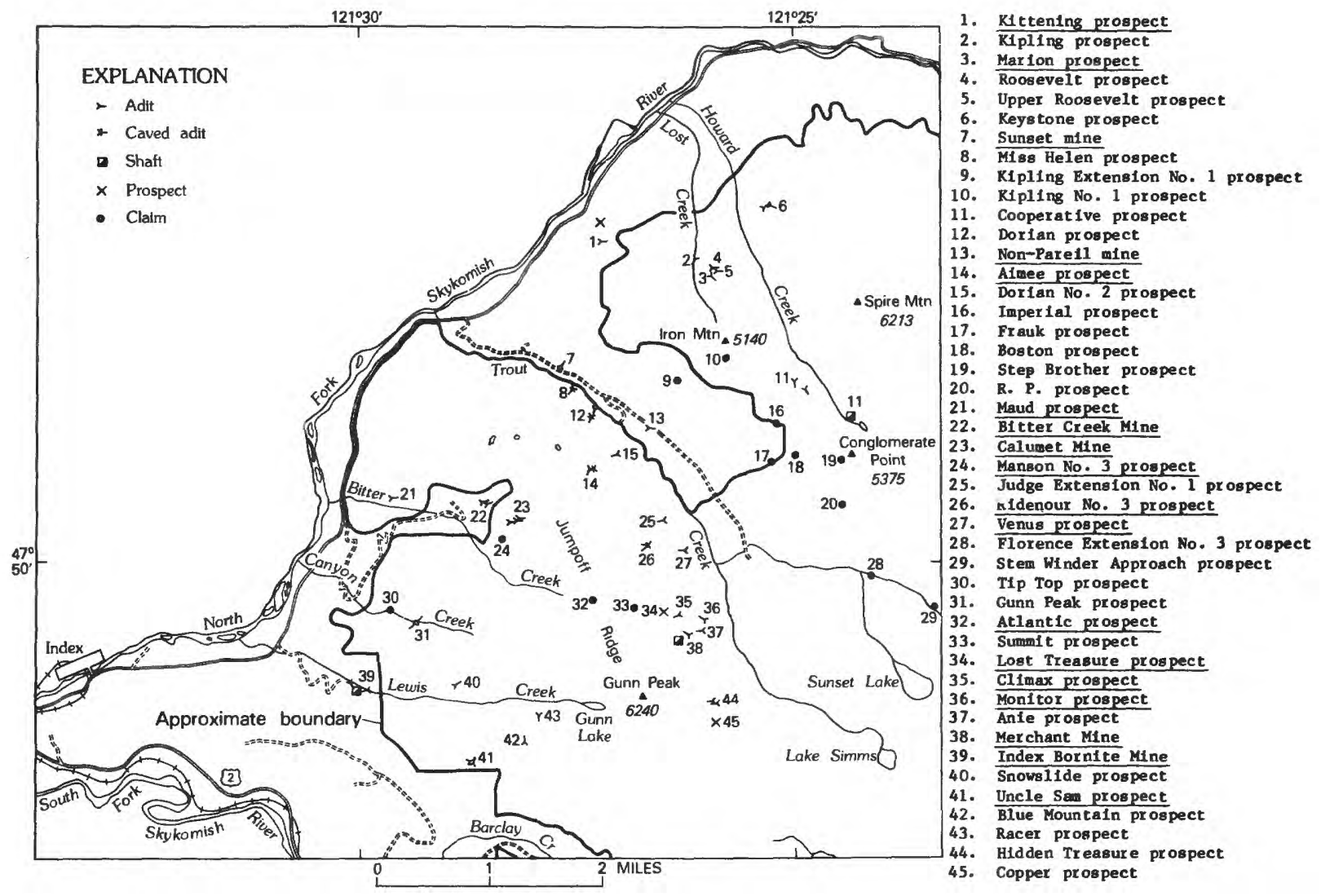

Figure 3.--Map showing mines and prospects in the eastern part of the Index mining district in the northwest part of Eagle Rock Roadless Area (numbered deposits are referred to in table 1; underlined names have possible undiscovered or identified resources) 
the Sunset mine at the turn of the century. Most prospecting and claim-staking occurred between 1895 and 1905, with little being done after 1910. More than 950 mining claims had been located in or near the roadless area by 1980 . Sixty-two claims are patented (Johnson and others, 1983).

Production from the Eagle Rock Roadless Area has been small, but the Sunset mine, $400 \mathrm{ft}$ northeast from the roadless area boundary, was the state's second largest copper producer. Mining ceased there in 1949 after production of nearly 13 million lb of copper, $156,000 \mathrm{oz}$ of silver, and $1,500 \mathrm{oz}$ of gold (Toepher, 1953).

During the three years ending in 1981, U.S. Bureau of Mines personnel examined mines, prospects, and claim groups in and near the roadless area. Additional data was obtained from county mining claim records, government files, and the literature. Forty-two underground and five surface mine workings (fig. 3) were examined, and where warranted, mapped and sampled. Analyses of nearly four hundred samples, taken from mine workings, outcrops, stockpiles, and dumps are on file at the U.S. Bureau of Mines, Western Field Operations Center, Spokane, Wash.

\section{ASSESSMENT OF MINERAL RESOURCE POTENTIAL}

Resource evaluation in the Eagle Rock Roadless Area is based on previous studies of mineralization and our concepts of ore genesis. This evaluation is focused on three areas of interest: the hydrothermal vein system associated with the Index batholith, the Merchant mine in the ancient melange rocks, and the metal anomaly pattern associated with the Grotto batholith.

The classification of mineral resources for known deposits found in the roadless area was made according to the terminology of U.S. Geological Survey Circular 831 (U.S. Bureau of Mines and U.S. Geological Survey, 1980). The classification of mineral potential of an area, however, represents an integration of measurable data and the subjective evaluation of the degree to which those data, and the interpretation of the geologic conditions inferred, represent a known mineral deposit type. We use three terms: high, moderate, and low, to define areas having the potential for mineral resources within the Eagle Rock Roadless Area. An area having a high potential for mineral resources is one in which most of the geologic criteria outlined in applicable mineral deposit models are met and a deposit of that general type and age exists in the western cordillera. An area having a moderate potential is one in which the geologic criteria permit a particular deposit type, but in which the geochemical or geophysical evidence for mineralization is less well defined; however, a reasonable chance for the occurrence of concealed mineral deposits exists. All other areas have a low potential either because we do not have sufficient geologic data or understanding to define a mineral deposit model, or because the data do not indicate geologic conditions favorable for ore accumulations. An area of low potential may include areas of concealed mineralization as well as areas of dispersed mineral occurrences.
Hydrothermal vein system

Weaver (1912) described the deposits of the Index district as lode deposits formed by deposition of ores from hydrothermal solutions in open veins. The hydrothermal vein system is restricted to the Index batholith and its nearby country rocks. Pyrite, bornite, chalcopyrite, and minor amounts of galena and sphalerite are common ore minerals. Locally, secondary minerals chalcocite, cuprite, and malachite were important. Weaver (1912, p. 59-61) noted that the distribution of ores within the vein system was related to rock type, with ores containing more copper and gold concentrated within the batholith. In the Sunset mine, which was a major producer from lode deposits, orthoclase is a common gangue mineral associated with the chalcopyrite zone (Grant, 1969, p. 78). Potassic alteration is prominent around veins and extends out into the granodiorite as much as a hundred feet or more. Some disseminated sulfides also occur. In contrast, galena and sphalerite, although they occur in all the veins, appear more prominent in and are closely associated with the pyrite and quartz veins deposited in the sedimentary rocks of the septum (Weaver, 1912, p. 62-63). The Keystone prospect is in the sedimentary septum, on the basis of Weaver's (1912, p. 79-80) description and field work, not in granitic rock of the Grotto batholith. The general distribution of minerals, ores, and associated potassic alteration reflects a hydrothermal zoning pattern suggesting that ore fluids in the veins within the Index batholith were at higher temperatures than those in the surrounding country rocks. Comparison of alteration patterns and mineralization of the hydrothermal vein system in the Index district with porphyry-copper systems exposed elsewhere in the Cascade Range (Grant, 1969) suggests that the Index hydrothermal vein system is similar to the porphyrycopper deposit model (Lowell and Guilbert, 1970).

There are, however, differences between the hydrothermal vein system described here and the porphyry-copper model. Those differences are primarily in the degree of fracturing of the host rock prior to emplacement of the hydrothermal system. We interpret the hydrothermal vein system to reflect emplacement in a competent host rock having widely-spaced joint system caused by structural deformation of the host, as opposed to internal deformation caused by the differentiating magmatic system that generally hosts the porphyry-copper deposit (Lowell and Guilbert, 1970). Of the forty-five mines and prospects examined, only the Sunset mine (no. 7 on fig. 3) has had significant production: 263,000 tons of copper ore, $156,000 \mathrm{oz}$ of silver, and 1,500 oz of gold (Toepfer, 1953). Previous investigations showed 134,500 tons of indicated resources averaging 3.69 percent copper and 173,000 tons of inferred resources averaging 3.28 percent copper (see table 1). Diamond drilling from level no. 2 has intersected two copper bearing zones south of the mine inside the roadless area.

Of the seventeen remaining mines and prospects examined that contain identified and potential resources (table 1), twelve lie within a portion of the hydrothermal vein system bounded on the north and 


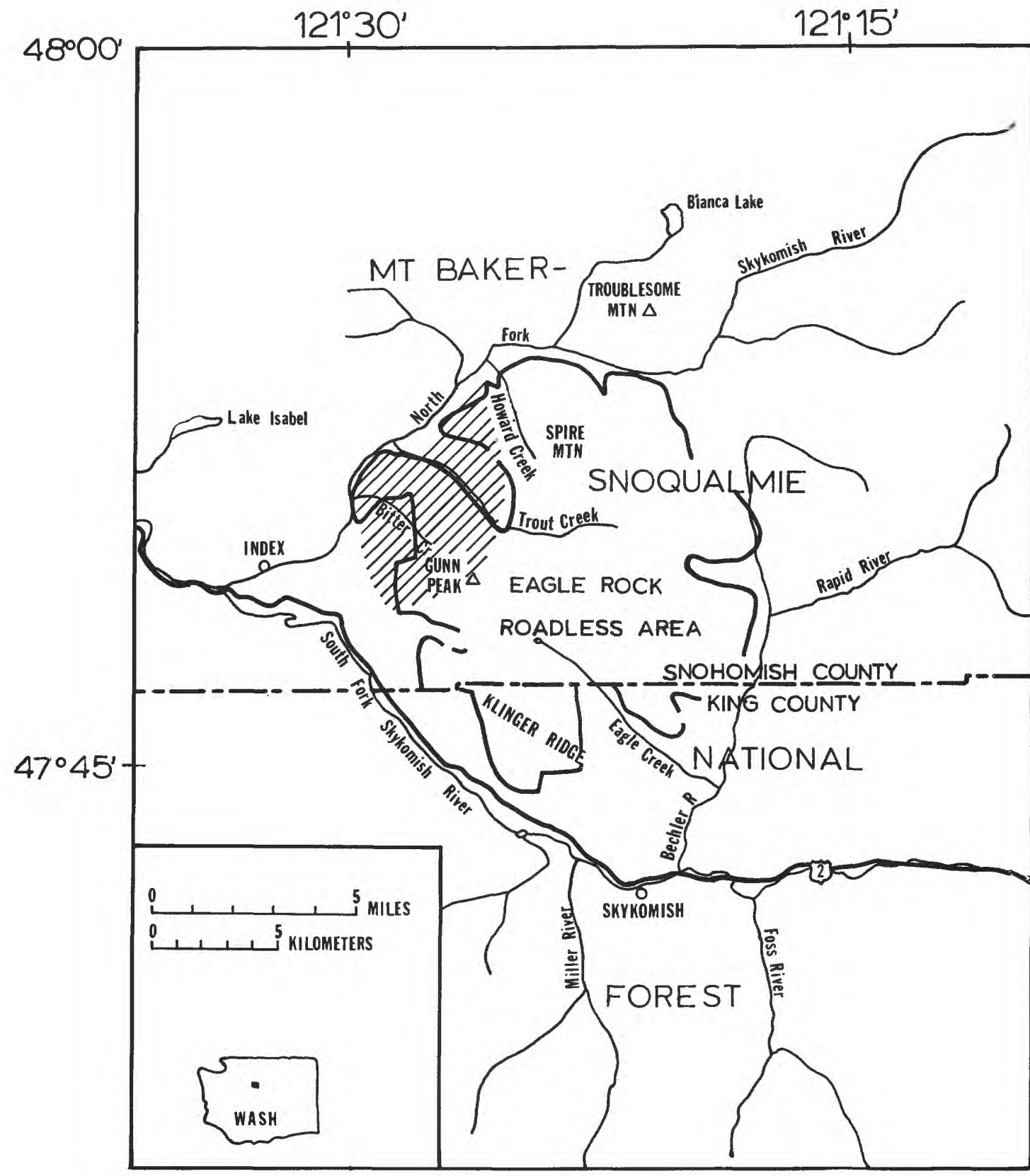

EXPLANATION

- APPROXIMATE BOUNDARY OF THE EAGLE ROCK ROADLESS AREA (06054)

ZD AREA OF MODERATE POTENTIAL FOR THE OCCURRENCE OF COPPER AND SILVER RESOURCES

Figure 4.--Mineral resource potential map of the Eagle Rock Roadless Area. 
east by Trout Creek and on the south by Bitter Creek (fig. 3). The grade at these occurrences ranges from 0.20 to 5.72 percent copper and as much as $4.2 \mathrm{oz}$ silver per ton. Samples analyzed from the Sunset mine (no. 7 on fig. 3) contain small amounts of chalcopyrite having anomalous concentrations of copper $\quad(>5,000$ $\mathrm{ppm})$, tin $(50 \mathrm{ppm})$, bismuth $(30 \mathrm{ppm})$, and tungsten (50-200 ppm) along with a trace of silver $(5 \mathrm{ppm}$, Church and others, 1983). Analyzed samples from the Bitter Creek adit (no. 22 on fig. 3) contain visible amounts of chalcopyrite, chalcocite, and sphalerite and have anomalous concentrations of manganese $(>5,000 \mathrm{ppm})$, silver (50-100 ppm), copper (10,000 ppm), lead $(5,000 \mathrm{ppm})$, and zinc $(3,000 \mathrm{ppm})$. Stream-sediment samples from this zone showed anomalous concentrations of cobalt, copper, molybdenum, tungsten, lead, zinc, and silver in many of these drainages, particularily those along the north side of Bitter Creek (Church and others, in press). The Kittening prospect (no. 1 on fig. 3) located outside the roadless area north of Trout Creek, contains mineralization that may extend into the roadless area, just as it extends to the west at the Ethel mine (Weaver, 1912). A moderate mineral potential for the occurrence of copper and silver resources in hydrothermal veins is indicated for the area of the outcrop of the Index batholith on the basis of surface data (see fig. 4). The pre-Tertiary/Swauk septum intruded by the Index batholith has a moderate, but less favorable potential for the occurrence of copper and silver resources on the basis of the hydrothermal zonation indicated by the mineral occurrences, the abundance of barren pyrite in the vein systems, and the sparcity of potassic alteration zones within the metamorphic rocks (Weaver, 1912; Church and others, 1983).

\section{Merchant mine}

The association of high concentrations of chalcopyrite in greenstone, the presence of magnetite, and the banded cherts found in the rocks exposed at the Merchant mine (table 1, no. 38) indicate that this deposit may not be related to the hydrothermal vein deposits described above. At one place in the mine (Johnson and others, 1983) the adit intersects the contact between the host rocks and an intrusive body (Index batholith). The granodiorite exposed in the mine has no sulfides present and there is no mineralization associated with the contact between this intrusive and the host rock. The field evidence at the Merchant mine is not sufficiently definitive to determine the type of deposit present. The ores in the Merchant mine may represent an interaction of the hydrothermal system described above with the metabasalts and banded cherts present in the host rocks, or they may represent a metamorphosed volcanogenic massive sulfide deposit of pre-Tertiary age. Geochemical results from the stream sediments indicate that copper and molybdenum concentrations are anomalous but zinc concentrations are not (Church and others, in press). Drainage basins to the east, along the strike of the host rocks, also contain anomalous values for lead, silver, bismuth, and cobalt. Nickel and vanadium concentrations are not anomalous. The geochemical signature in stream sediments is very similar to that for the hydrothermal system found in drainages from the main part of the Index mining district.

\section{Grotto batholith}

The drainages in the outcrop area of the Grotto batholith have a much larger number of geochemical anomalies than drainages in other rocks of the roadless drea. Stream-sediment data from the basins and tributaries of the upper reaches of Trout and Howard Creeks indicate a widespread geochemical anomaly. Anomalous values for copper, cobalt, barium, molybdenum, tungsten, gold, lead, silver, and bismuth occur in these basins. In the Howard Creek drainage, in talus below Conglomerate Point, we found iron-stained, sheared granodiorite that contained galena, sphalerite, and tourmaline. However, a sample of the breccia from Conglomerate Point, and an altered sample from talus below the breccia contained no visible sulfides and has no anomalous metal values. Samples from an oxidized zone on Spire Mountain contained high concentrations of copper (200-300 ppm) and detectable values for silver and bismuth (Church and others, 1983).

Many of the other stream drainage basins that are partially or wholly underlain by the Grotto batholith show anomalous values for selected elements (Church and others, in press), particularly for copper, cobalt, molybdenum, tungsten, lead, and silver. A sample collected from Klinger Ridge near the contact of the Grotto batholith with the melange contained veins of epidote and quartz having concentrations of boron as much as $100 \mathrm{ppm}$, barium as much as 500 $\mathrm{ppm}$, and copper as much as $500 \mathrm{ppm}$. In spite of the fact that numerous geochemical indications of mineralization are present within the Grotto batholith, field examination failed to locate significant zones of alteration or hydrothermal vein systems exposed within the Grotto batholith or notable mineralization associated with the contact of the batholith in the country rocks. We have therefore assigned a low potential for the occurrence of base- and preciousmetal resources in the outcrop area of the Grotto batholith.

\section{REFERENCES CTTED}

Church, S. E., Frisken, J. G., Mosier, E. L., and Willson, W. R., in press, Geochemical maps of the Eagle Rock and Glacier Peak Roadless Areas, Snohomish and King Counties, Washington: U.S. Geological Survey Miscellaneous Field Studies Map MF-1380-D, scale $1: 100,000$.

Church, S. E., Mosier, E. L., Frisken, J. G., Arbogast, B. F., and McDougal, C. M., 1982, Analytical results from stream sediments and panned concentrates from stream sediments collected from the Monte Cristo and Eagle Rock study areas, Washington: U.S. Geological Survey OpenFile Report 82-303, 83 p.

Church, S. E., Mosier, E. L., Tabor, R. W., Willson, W. R., and McDougal, C. M., 1983, Analytical results and statistical analysis of rocks, ores, and stream pebbles from the Eagle Rock and Glacier Peak Roadless Areas, Snohomish and King Counties, Washington: U.S. Geological Survey Open-File Report 83-342, 84 p. 
[Underlined names have possible undiscovered or identified resources]

\begin{tabular}{|c|c|c|c|c|}
\hline $\begin{array}{l}\text { Map no. } \\
\text { (fig. 3) }\end{array}$ & Name & Summary & $\begin{array}{l}\text { Workings and } \\
\text { production }\end{array}$ & Resource and sample data \\
\hline 1 & $\frac{\text { Kittening }}{\text { prospect. }}$ & $\begin{array}{l}\text { East-trending, south-dipping } \\
\text { sulfide-bearing quartz vein } \\
\text { and shear zone averaging } \\
5.3 \mathrm{ft} \text { thick in quartz } \\
\text { diorite; about } 700 \mathrm{ft} \text { west } \\
\text { of roadless area. }\end{array}$ & $\begin{array}{l}\text { One } 425-f t-l \text { ong adit } \\
\text { and one trench. } \\
\text { According to the } \\
\text { Northwest Mining } \\
\text { Journal ( } 1909 \text { ), } \\
\text { the mine dump was } \\
\text { shipped to a } \\
\text { smelter. }\end{array}$ & $\begin{array}{l}\text { Twenty-seven samples: } \\
\text { twenty-one assayed from } \\
0.32 \text { to } 13.0 \text { percent } \\
\text { copper. Resources are } \\
\text { at least } 200,000 \text { tons } \\
\text { averaging } 0.72 \text { percent } \\
\text { copper. }\end{array}$ \\
\hline 2 & $\begin{array}{l}\text { Kipling } \\
\text { prospect. }\end{array}$ & $\begin{array}{l}\text { Limonite-stained, fractured } \\
\text { gray quartzite. }\end{array}$ & One $30-f t-l o n g$ adit & $\begin{array}{l}\text { One sample assayed no } \\
\text { appreciable metallic } \\
\text { minerals. }\end{array}$ \\
\hline 3 & $\frac{\text { Marion }}{\text { prospect. }}$ & $\begin{array}{l}\text { Sulfide-bearing shear zones } \\
\text { in dark-gray, fine-grained } \\
\text { quartzite. }\end{array}$ & $\begin{array}{l}\text { One } 38-f t-l o n g \text { adit } \\
\text { and connecting } \\
30-f t-l o n g \text { drift. }\end{array}$ & $\begin{array}{l}\text { Seven samples: one } \\
\text { assayed } 1.3 \text { oz silver } \\
\text { per ton and } 1.0 \text { percent } \\
\text { copper. Another } \\
\text { assayed } 0.40 \text { percent } \\
\text { copper. The remaining } \\
\text { samples assayed less } \\
\text { than } 0.07 \text { percent } \\
\text { copper. }\end{array}$ \\
\hline 4 & $\begin{array}{l}\text { Roosevelt } \\
\text { prospect. }\end{array}$ & $\begin{array}{l}\text { Limonite-stained gray } \\
\text { quartzite and granodiorite. }\end{array}$ & $\begin{array}{l}\text { One } 56-f t-l \text { ong adit } \\
\text { with a } 10-f t-l \text { ong } \\
\text { drift. }\end{array}$ & $\begin{array}{l}\text { Four samples assayed no } \\
\text { appreciable metallic } \\
\text { minerals. }\end{array}$ \\
\hline 5 & $\begin{array}{l}\text { Upper } \\
\text { Roosevelt } \\
\text { prospect. }\end{array}$ & $\begin{array}{l}\text { Sulfide-bearing shear zones } \\
\text { and pods in gray quartzite. }\end{array}$ & $\begin{array}{l}\text { One } 17-f t-1 \text { ong adit } \\
\text { with a 10-ft-long } \\
\text { drift. }\end{array}$ & $\begin{array}{l}\text { Seven samples: five } \\
\text { assayed from } 0.2 \text { to } 3.3 \\
\text { oz silver per ton and } \\
\text { from } 0.20 \text { to } 2.4 \\
\text { percent copper. }\end{array}$ \\
\hline 6 & $\begin{array}{l}\text { Keystone } \\
\text { prospect. }\end{array}$ & $\begin{array}{l}\text { Irregular northeast-striking } \\
\text { steeply dipping, sulfide- } \\
\text { bearing shear zones in } \\
\text { quartzite. }\end{array}$ & $\begin{array}{l}\text { Two adits, } 267 \text { and } \\
96 \mathrm{ft} \text { long. }\end{array}$ & $\begin{array}{l}\text { Thirteen samples: } \\
\text { three assayed from } 0.18 \\
\text { to } 0.60 \text { percent copper. }\end{array}$ \\
\hline 7 & $\frac{\text { Sunset }}{\text { mine. }}$ & $\begin{array}{l}\text { East-west trending, north- } \\
\text { dipping, and northwest- } \\
\text { trending, northeast-dipping, } \\
\text { sulfide-bearing veins and } \\
\text { shear zones in quartz } \\
\text { diorite; about } 400 \mathrm{ft} \\
\text { northeast of the roadless } \\
\text { area. }\end{array}$ & $\begin{array}{l}\text { Large, multilevel } \\
\text { underground mine. } \\
\text { Production con- } \\
\text { sisted of nearly } \\
13 \text { million lb of } \\
\text { copper, } 156,000 \\
\text { oz of silver and } \\
1,500 \text { oz of gold } \\
\text { (Toepher, 1953). }\end{array}$ & $\begin{array}{l}\text { No samples were taken } \\
\text { during the present } \\
\text { study. A } 1950 \text { Bureau } \\
\text { of Mines investigation } \\
\text { (Magill, unpub. data, } \\
\text { 1952) showed indicated } \\
\text { resources are } 134,500 \\
\text { tons averaging } 3.69 \\
\text { percent copper, and } \\
\text { inferred resources are } \\
173,000 \text { tons averaging } \\
3.28 \text { percent copper. } \\
\text { These resources are } \\
\text { outside the roadless } \\
\text { area. A drill hole } \\
\text { intersects two copper- } \\
\text { bearing zones in the } \\
\text { roadless area. }\end{array}$ \\
\hline 8 & $\begin{array}{l}\text { Miss Helen } \\
\text { prospect. }\end{array}$ & 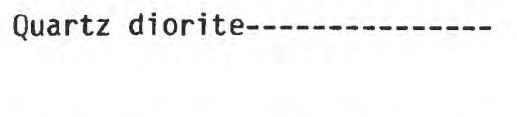 & One caved adit-....- & $\begin{array}{l}\text { One sample assayed no } \\
\text { appreciable metallic } \\
\text { minerals. }\end{array}$ \\
\hline 9 & $\begin{array}{l}\text { Kipling } \\
\text { Extension } \\
\text { No. } 1 \\
\text { prospect. }\end{array}$ & $\begin{array}{l}\text { Fractured, limonite-stained } \\
\text { quartz diorite containing } \\
\text { traces of pyrite and } \\
\text { chalcopyrite locally; about } \\
800 \mathrm{ft} \text { southwest of the } \\
\text { roadless area. }\end{array}$ & None--..- & $\begin{array}{l}\text { One sample assayed no } \\
\text { appreciable metallic } \\
\text { minerals. }\end{array}$ \\
\hline
\end{tabular}


Table 1.--Mines and prospects in and near the Eagle Rock Roadless Area--Continued

\begin{tabular}{|c|c|c|c|c|}
\hline $\begin{array}{l}\text { Map no. } \\
\text { (fig. } 3 \text { ) }\end{array}$ & Name & Summary & $\begin{array}{l}\text { Workings and } \\
\text { production }\end{array}$ & Resource and sample data \\
\hline 10 & $\begin{array}{l}\text { Kipling } \\
\text { No. } 1 \\
\text { prospect. }\end{array}$ & $\begin{array}{l}\text { Fractured, limonite-stained } \\
\text { quartzite containing dissem- } \\
\text { inated pyrite locally. }\end{array}$ & None-1-n- & $\begin{array}{l}\text { Two samples assayed no } \\
\text { appreciable metallic } \\
\text { minerals. }\end{array}$ \\
\hline 11 & $\begin{array}{l}\text { Cooperative } \\
\text { prospect. }\end{array}$ & $\begin{array}{l}\text { Northwest-trending, steeply } \\
\text { dipping, sulfide-bearing } \\
\text { shear zones in quartz } \\
\text { diorite. }\end{array}$ & $\begin{array}{l}\text { Two adits, } 684 \text { and } \\
59 \mathrm{ft} \text { long. }\end{array}$ & $\begin{array}{l}\text { Twenty-two samples } \\
\text { assayed no appreciable } \\
\text { metallic minerals. }\end{array}$ \\
\hline 12 & $\begin{array}{l}\text { Dorian } \\
\text { prospect. }\end{array}$ & Quartz diorite and alluvium & $\begin{array}{l}\text { Two adits, one } \\
\text { partially caved in } \\
\text { alluvium, the other } \\
\text { completely caved in } \\
\text { quartz diorite }\end{array}$ & $\begin{array}{l}\text { Four samples assayed no } \\
\text { appreciable metallic } \\
\text { minerals. }\end{array}$ \\
\hline 13 & $\frac{\text { Non-Pareil }}{\text { mine. }}$ & $\begin{array}{l}\text { Northeast- and northwest- } \\
\text { trending, steeply dipping } \\
\text { sulfide-bearing shear zones } \\
\text { in quartz diorite; about } \\
700 \mathrm{ft} \text { northeast of road- } \\
\text { less area. Three zones } \\
\text { averaging } 3.0 \mathrm{ft} \text { thick } \\
\text { contain copper and silver } \\
\text { minerals. }\end{array}$ & $\begin{array}{l}\text { Underground workings } \\
\text { total 1,051 ft } \\
\text { including drifts } \\
\text { and crosscuts. } \\
\text { Several opencuts } \\
\text { and a } 300-\text { ft-long } \\
\text { adit are reported } \\
\text { above main adit } \\
\text { (Magi11, unpub. } \\
\text { data, 1957). }\end{array}$ & $\begin{array}{l}\text { Thirty-five samples: ten } \\
\text { assayed from } 0.20 \text { to } \\
1.9 \text { percent copper. } \\
\text { There are at least } \\
80,000 \text { tons averaging } \\
0.22 \text { percent copper. }\end{array}$ \\
\hline 14 & $\frac{\text { Aimee }}{\text { prospect. }}$ & $\begin{array}{l}\text { Northeast-trending, northwest- } \\
\text { dipping, sulfide-bearing } \\
\text { zone averaging } 1.8 \mathrm{ft} \text { thick } \\
\text { in a mafic dike. }\end{array}$ & $\begin{array}{l}\text { One caved adit and a } \\
28-f t-1 \text { ong adit. }\end{array}$ & $\begin{array}{l}\text { Eight samples: six } \\
\text { samples assayed from } \\
0.21 \text { to } 14.00 \text { percent } \\
\text { copper. Four samples } \\
\text { assayed from } 0.5 \text { to } 2.1 \\
\text { oz silver per ton. } \\
\text { Mineralized zone only } \\
\text { exposed over } 15 \mathrm{ft} \\
\text { strike length averages } \\
5.72 \text { percent copper and } \\
1.7 \text { oz silver per ton. }\end{array}$ \\
\hline 15 & $\begin{array}{l}\text { Dorian } \\
\text { No. } 2 \\
\text { prospect. }\end{array}$ & $\begin{array}{l}\text { N. } 77^{\circ} \text { E. trending, } 79^{\circ} \mathrm{NW} . \\
\text { dipping shear zone in } \\
\text { quartz diorite. }\end{array}$ & One $28-f t-1$ ong adit & $\begin{array}{l}\text { Two samples assayed no } \\
\text { appreciable metallic } \\
\text { minerals. }\end{array}$ \\
\hline 16 & $\begin{array}{l}\text { Imperial } \\
\text { prospect. }\end{array}$ & $\begin{array}{l}\text { Limonite-stained, fractured } \\
\text { quartz diorite containing } \\
\text { disseminated pyrite locally. }\end{array}$ & None-n- & $\begin{array}{l}\text { One sample assayed no } \\
\text { appreciable metallic } \\
\text { minerals. }\end{array}$ \\
\hline 17 & $\begin{array}{l}\text { Frauk } \\
\quad \text { prospect. }\end{array}$ & $\begin{array}{l}\text { Quartz monzonite containing } \\
\text { disseminated pyrite. }\end{array}$ & ---- do $-\cdots---n-n-\cdots$ & $\begin{array}{l}\text { One sample assayed } 1.0 \mathrm{oz} \\
\text { silver per ton. }\end{array}$ \\
\hline 18 & $\begin{array}{l}\text { Boston } \\
\text { prospect. }\end{array}$ & $\begin{array}{l}\text { Greenish-gray, sulfide- } \\
\text { bearing, porphyritic } \\
\text { andesite float. }\end{array}$ & --- do- & $\begin{array}{l}\text { One sample assayed } 0.4 \mathrm{oz} \\
\text { silver per ton and } 0.77 \\
\text { percent zinc. }\end{array}$ \\
\hline 19 & $\begin{array}{l}\text { Step } \\
\text { Brother } \\
\text { prospect. }\end{array}$ & $\begin{array}{l}\text { Volcanic breccia containing } \\
\text { disseminated pyrite. }\end{array}$ & 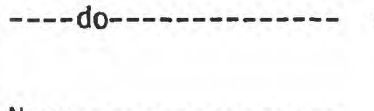 & $\begin{array}{l}\text { One sample assayed no } \\
\text { appreciable metallic } \\
\text { minerals. }\end{array}$ \\
\hline 20 & $\begin{array}{l}\text { R. P. } \\
\text { prospect. }\end{array}$ & $\begin{array}{l}\text { Limonite-stained quartz } \\
\text { monzonite. }\end{array}$ & None-n-n- & Do. \\
\hline 21 & $\frac{\text { Maud }}{\text { prospect. }}$ & $\begin{array}{l}\text { N. } 80^{\circ} \text { E. trending, } 75^{\circ} \text { SE. } \\
\text { dipping, sulfide-bearing } \\
\text { shear zone averaging } 1.8 \mathrm{ft} \\
\text { thick in quartz diorite. }\end{array}$ & One 89-ft-1ong adit & $\begin{array}{l}\text { Four samples: two } \\
\text { assayed } 0.21 \text { and } 0.33 \\
\text { percent copper. } \\
\text { Eighty-nine-ft exposed } \\
\text { zone averages } 0.20 \\
\text { percent copper. }\end{array}$ \\
\hline 22 & $\frac{\text { Bitter }}{\text { Creek }}$ & $\begin{array}{l}\text { N. } 70^{\circ} \text { E. trending, } 75^{\circ} \mathrm{NW} \text {. } \\
\text { dipping, sulfide-bearing } \\
\text { shear zone averaging } 2.2 \\
\text { ft thick in quartz diorite; }\end{array}$ & $\begin{array}{l}\text { Two adits, } 145 \text { and } \\
600 \mathrm{ft} \text { long. }\end{array}$ & $\begin{array}{l}\text { Eleven samples; three } \\
\text { assayed from } 0.31 \text { to } \\
2.5 \text { percent copper. }\end{array}$ \\
\hline
\end{tabular}


Table 1.--Mines and prospects in and near the Eagle Rock Roadless Area--Continued

\begin{tabular}{|c|c|c|c|c|}
\hline $\begin{array}{l}\text { Map no. } \\
\text { (fig. } 3)\end{array}$ & Name & Summary & $\begin{array}{l}\text { Workings and } \\
\text { production }\end{array}$ & Resource and sample data \\
\hline 23 & $\frac{\text { Calumet }}{\text { mine. }}$ & $\begin{array}{l}\text { Northeast-trending, } \\
\text { southeast-dipping, sulfide- } \\
\text { bearing shear zone averag- } \\
\text { ing } 4 \mathrm{ft} \text { thick in quartz } \\
\text { diorite. }\end{array}$ & $\begin{array}{l}\text { Three adits have a } \\
\text { combined length of } \\
646 \mathrm{ft} \text { including } \\
\text { drifts and cross- } \\
\text { cuts. The upper } \\
\text { adit has a large } \\
\text { shaft or underhand } \\
\text { stope of unknown } \\
\text { depth. }\end{array}$ & $\begin{array}{l}\text { Forty-seven samples: } \\
\text { twenty-five assayed } \\
\text { from } 0.20 \text { to } 10.6 \\
\text { percent copper and from } \\
0.06 \text { to } 6.75 \text { percent } \\
\text { zinc. There are about } \\
12,000 \text { tons averaging } \\
0.90 z \text { silver per ton, } \\
191 \text { percent copper, } \\
\text { and } 1.0 \text { percent zinc. } \\
\text { A high grade zone in } \\
\text { the deposit contains } \\
\text { nearly } 3,000 \text { tons } \\
\text { averaging over } 3.2 \\
\text { percent copper. }\end{array}$ \\
\hline 24 & $\frac{\text { Manson }}{\frac{\text { No. } 3}{\text { prospect. }}}$ & $\begin{array}{l}\text { N. } 80^{\circ} \text { E. trending, } 80^{\circ} \text { SE. } \\
\text { dipping, sulfide-bearing } \\
\text { quartz vein averaging } 1.1 \\
\text { ft thick in sheared quartz } \\
\text { diorite. }\end{array}$ & None-- & $\begin{array}{l}\text { Three samples; they } \\
\text { assayed from } 0.12 \text { to } \\
5.35 \text { percent copper } \\
\text { and from } 0.8 \text { to } 2.8 \text { oz } \\
\text { silver per ton. There } \\
\text { are } 700 \text { tons averaging } \\
1.3 \text { oz silver per ton } \\
\text { and } 1.34 \text { percent } \\
\text { copper. }\end{array}$ \\
\hline 25 & $\begin{array}{l}\text { Judge } \\
\text { Extension } \\
\text { No. } 1 \\
\text { prospect. }\end{array}$ & $\begin{array}{l}\text { N. } 70^{\circ} \text { W. striking, } 73^{\circ} \mathrm{NE} \text {. } \\
\text { dipping shear zone in } \\
\text { quartz diorite. }\end{array}$ & One 114-ft-1ong adit & $\begin{array}{l}\text { One sample assayed no } \\
\text { appreciable metallic } \\
\text { minerals. }\end{array}$ \\
\hline 26 & $\frac{\text { Ridenour }}{\frac{\text { No. } 3}{\text { prospect. }}}$ & $\begin{array}{l}\text { Northeast- and northwest- } \\
\text { trending, steeply dipping, } \\
\text { sulfide-bearing shear zones } \\
\text { in quartz diorite. }\end{array}$ & $\begin{array}{l}\text { Two adits, } 96 \text { and } \\
60 \mathrm{ft} \text { long. }\end{array}$ & $\begin{array}{l}\text { Six samples: five } \\
\text { assayed from } 0.12 \text { to } \\
1.8 \text { percent copper. }\end{array}$ \\
\hline 27 & $\frac{\text { Venus }}{\text { prospect. }}$ & $\begin{array}{l}\text { N. } 78^{\circ} \text { W. trending, steeply } \\
\text { dipping, sulfide-bearing } \\
\text { shear zone in quartz } \\
\text { diorite. }\end{array}$ & $\begin{array}{l}\text { One } 123-\mathrm{ft}-1 \text { ong } \\
\text { adit with } 30-\mathrm{ft}- \\
\text { long crosscut. }\end{array}$ & $\begin{array}{l}\text { Four samples: two } \\
\text { assayed } 0.17 \text { and } \\
0.88 \text { percent copper. }\end{array}$ \\
\hline 28 & $\begin{array}{l}\text { Florence } \\
\text { Extension } \\
\text { No. } 3 \\
\text { prospect. }\end{array}$ & $\begin{array}{l}\text { Limonite-stained shear zone } \\
\text { in quartz monzonite. }\end{array}$ & 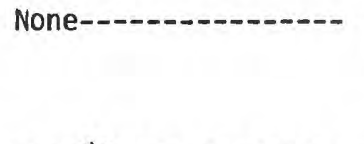 & $\begin{array}{l}\text { Three samples assayed no } \\
\text { appreciable metallic } \\
\text { minerals. }\end{array}$ \\
\hline 29 & $\begin{array}{l}\text { Stem winder } \\
\text { Approach } \\
\text { prospect. }\end{array}$ & Quartz monzonite-.... & 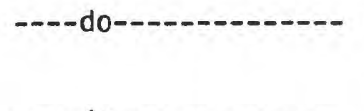 & $\begin{array}{l}\text { One sample assayed no } \\
\text { appreciable metallic } \\
\text { minerals. }\end{array}$ \\
\hline 30 & $\begin{array}{l}\text { Tip Top } \\
\text { prospect. }\end{array}$ & $\begin{array}{l}\text { Northwest trending, northeast } \\
\text { dipping, shear zones in } \\
\text { quartz diorite. }\end{array}$ & 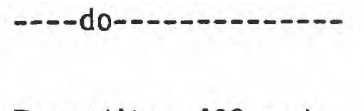 & $\begin{array}{l}\text { Four samples assayed no } \\
\text { appreciable metallic } \\
\text { minerals. }\end{array}$ \\
\hline 31 & $\begin{array}{l}\text { Gunn Peak } \\
\text { prospect. }\end{array}$ & $\begin{array}{l}\text { N. } 70^{\circ} \text { E. striking, steeply } \\
\text { dipping, sulfide-bearing } \\
\text { shear zones in quartz } \\
\text { diorite. }\end{array}$ & $\begin{array}{l}\text { Two adits, } 492 \text { and } \\
5 \mathrm{ft} \text { long. }\end{array}$ & $\begin{array}{l}\text { Twenty-five samples: } \\
\text { only one had signifi- } \\
\text { cant metallic mineral } \\
\text { concentrates; it } \\
\text { assayed } 1.0 \mathrm{Oz} \text { silver } \\
\text { per ton and } 1.6 \text { percent } \\
\text { copper. }\end{array}$ \\
\hline
\end{tabular}


Table 1.--Mines and prospects in and near the Eagle Rock Roadless Area--Continued

\begin{tabular}{|c|c|c|c|c|}
\hline $\begin{array}{l}\text { Map no. } \\
\text { (fig. } 3 \text { ) }\end{array}$ & Name & Summary & $\begin{array}{c}\text { Workings and } \\
\text { production }\end{array}$ & Resource and sample data \\
\hline 32 & $\frac{\text { Atlantic }}{\text { prospect. }}$ & $\begin{array}{l}\text { N. } 85^{\circ} \text { E. trending, } 65^{\circ} \mathrm{SE} \text {. } \\
\text { dipping, siliceous, sulfide- } \\
\text { bearing zone averaging } 2.0 \\
\text { ft thick in sheared quartz } \\
\text { diorite. }\end{array}$ & None-- & $\begin{array}{l}\text { Two samples: they } \\
\text { assayed } 1.0 \text { and } 9.4 \mathrm{oz} \\
\text { silver per ton, } 0.84 \\
\text { and } 1.28 \text { percent } \\
\text { copper, as much as } 0.25 \\
\text { percent zinc, and as } \\
\text { much as } 7.66 \text { percent } \\
\text { arsenic. There are } \\
\text { about } 2,300 \text { tons } \\
\text { averaging } 4.2 \text { oz silver } \\
\text { per ton and } 1.0 \text { percent } \\
\text { copper. }\end{array}$ \\
\hline 33 & $\begin{array}{l}\text { Summit } \\
\text { prospect. }\end{array}$ & $\begin{array}{l}\text { N. } 84^{\circ} \text { W. striking, } 81^{\circ} \mathrm{NE} \text {. } \\
\text { dipping, sulfide-bearing } \\
\text { quartz vein in quartz } \\
\text { diorite. }\end{array}$ & None & $\begin{array}{l}\text { One sample assayed } 0.05 \\
\text { percent copper. }\end{array}$ \\
\hline 34 & $\frac{\text { Lost }}{\frac{\text { Treasure }}{\text { prospect }}}$ & $\begin{array}{l}\text { N. } 88^{\circ} \text { E. trending, } 86^{\circ} \mathrm{SE} \text {. } \\
\text { dipping, } 170-\mathrm{ft}-\mathrm{long} \\
\text { sulfide-bearing shear zone } \\
\text { averaging } 3.7 \mathrm{ft} \text { thick } \\
\text { in quartz diorite. }\end{array}$ & $\begin{array}{l}\text { One } 10-f t-1 \text { ong } \\
\text { opencut. }\end{array}$ & $\begin{array}{l}\text { Six samples: four } \\
\text { assayed from } 0.8 \text { to } \\
22.4 \text { oz silver per ton; } \\
\text { five assayed from } 0.53 \\
\text { to } 25.0 \text { percent copper. } \\
\text { There are at least } \\
4,500 \text { tons averaging } \\
0.9 \text { oz silver per ton } \\
\text { and } 1.13 \text { percent } \\
\text { copper. }\end{array}$ \\
\hline 35 & $\frac{\text { climax }}{\text { prospect. }}$ & $\begin{array}{l}\text { Northeast-trending, northwest- } \\
\text { dipping, sulfide-bearing } \\
\text { quartz veins averaging } 0.7 \\
\text { ft thick and shear zones } \\
\text { averaging } 2.3 \mathrm{ft} \text { thick in } \\
\text { quartz diorite. }\end{array}$ & $\begin{array}{l}\text { One adit, caved } 30 \\
\text { ft from portal. }\end{array}$ & $\begin{array}{l}\text { Six samples: four } \\
\text { assayed from } 0.4 \text { to } 3.2 \\
\text { oz silver per ton and } \\
\text { from } 0.60 \text { to } 5.7 \text { per- } \\
\text { cent copper. There are } \\
\text { about } 1,300 \text { tons } \\
\text { averaging } 0.3 \text { oz silver } \\
\text { per ton and } 0.53 \text { per- } \\
\text { cent copper. }\end{array}$ \\
\hline 36 & $\frac{\text { Monitor }}{\text { prospect. }}$ & $\begin{array}{l}\text { N. } 66^{\circ} \text { W. trending, } 46^{\circ} \mathrm{NE} \text {. } \\
\text { dipping, sulfide-bearing } \\
\text { shear zone averaging } 0.7 \mathrm{ft} \\
\text { thick in quartzite and } \\
\text { argillite. }\end{array}$ & $\begin{array}{l}\text { One 26-ft-long adit } \\
\text { and an opencut. }\end{array}$ & $\begin{array}{l}\text { Five samples: two } \\
\text { assayed } 0.4 \text { and } 1.0 \mathrm{oz} \\
\text { silver per ton and } 0.31 \\
\text { and } 1.64 \text { percent } \\
\text { copper. Only about } 100 \\
\text { tons averaging } 0.70 z \\
\text { silver per ton and } 1.07 \\
\text { percent copper can be } \\
\text { estimated from limited } \\
\text { exposures. }\end{array}$ \\
\hline 37 & $\begin{array}{l}\text { Anie } \\
\text { prospect. }\end{array}$ & $\begin{array}{l}\text { Pyrite veinlets in } \\
\text { siliceous argillite. }\end{array}$ & lone 26-ft-1ong adit & $\begin{array}{l}\text { One sample assayed no } \\
\text { appreciable metallic } \\
\text { minerals. }\end{array}$ \\
\hline 38 & $\frac{\text { Merchant }}{\text { mine. }}$ & $\begin{array}{l}\text { Northwest-trending, southwest- } \\
\text { dipping, sulfide-bearing } \\
\text { shear zones averaging } 4.9 \\
\text { ft thick and a northeast- } \\
\text { trending, sulfide-bearing } \\
\text { siliceous zone averaging } 30 \\
\text { ft thick in metamorphic } \\
\text { rock. This may be a sub- } \\
\text { marine volcanogenic, } \\
\text { massive-sulfide deposit. }\end{array}$ & $\begin{array}{l}\text { One adit, with } \\
2,040 \text { ft of work- } \\
\text { ings, including } \\
\text { crosscuts and } \\
\text { drifts and one } \\
\text { shaft. Some } \\
\text { production may } \\
\text { have come from a } \\
\text { stope or large } \\
\text { raise. }\end{array}$ & $\begin{array}{l}\text { Eighty-two samples: } \\
\text { twenty-two assayed } \\
\text { from } 0.2 \text { to } 1.5 \text { oz } \\
\text { silver per ton. Thirty } \\
\text { samples assayed from } \\
0.20 \text { to } 5.4 \text { percent } \\
\text { copper. There are at } \\
\text { least } 600,000 \text { tons } \\
\text { averaging } 0.34 \text { percent } \\
\text { copper. }\end{array}$ \\
\hline
\end{tabular}


Table 1.--Mines and prospects in and near the Eagle Rock Roadless Area--Continued

\begin{tabular}{|c|c|c|c|c|}
\hline $\begin{array}{l}\text { Map no. } \\
\text { (fig. } 3 \text { ) }\end{array}$ & Name & Summary & $\begin{array}{l}\text { Workings and } \\
\text { production }\end{array}$ & Resource and sample data \\
\hline 39 & $\frac{\frac{\text { Index }}{\text { Bornite }}}{\text { mine. }}$ & $\begin{array}{l}\text { N. } 65^{\circ} \text { E. trending, } 75^{\circ} \mathrm{SE} \text {. } \\
\text { dipping, sulfide-bearing } \\
\text { quartz-calcite vein } \\
\text { averaging } 0.8 \mathrm{ft} \text { thick } \\
\text { and sulfide-bearing } \\
\text { mafic dike averaging } \\
2.4 \mathrm{ft} \text { thick in quartz } \\
\text { diorite; about } 600 \mathrm{ft} \text { west } \\
\text { of roadless area. }\end{array}$ & $\begin{array}{l}\text { Two adits, } 57 \text { and } \\
522 \mathrm{ft} \text { long, } \\
\text { including cross- } \\
\text { cuts and drifts, } \\
\text { and one shaft that } \\
\text { may access a } \\
\text { sublevel. }\end{array}$ & $\begin{array}{l}\text { Twenty-five samples: } \\
\text { eleven assayed from } 0.2 \\
\text { to } 8.6 \text { oz silver per } \\
\text { ton, sixteen assayed } \\
\text { from } 0.31 \text { to } 55.0 \\
\text { percent copper. only } \\
\text { about } 9,300 \text { tons } \\
\text { averaging } 1.23 \text { percent } \\
\text { copper and } 0.2 \text { oz per } \\
\text { ton can be estimated. }\end{array}$ \\
\hline 40 & $\begin{array}{l}\text { Snowslide } \\
\text { prospect. }\end{array}$ & $\begin{array}{l}\text { Gray metaquartzite with } \\
\text { sulfide-bearing pods. }\end{array}$ & one $13-f t-1$ ong adit & $\begin{array}{l}\text { One sample assayed } 0.38 \\
\text { percent copper. }\end{array}$ \\
\hline 41 & $\frac{\text { Uncle }}{\frac{\text { Sam }}{\text { prospect. }}}$ & $\begin{array}{l}\text { Irregular and discontinuous } \\
\text { sulfide-bearing fractures } \\
\text { and disseminated sulfide } \\
\text { minerals in quartzite. }\end{array}$ & $\begin{array}{l}\text { Two adits, } 70 \text { and } 8 \\
\text { ft long. According } \\
\text { to Weaver (1912), } \\
\text { there should be } \\
\text { three adits } \\
\text { totaling } 400 \mathrm{ft} \\
\text { at the property. }\end{array}$ & $\begin{array}{l}\text { Eight samples: seven } \\
\text { assayed from } 0.2 \text { to } 0.4 \\
\text { oz silver per ton. } \\
\text { Three assayed from } 0.19 \\
\text { to } 1.0 \text { percent copper. }\end{array}$ \\
\hline 42 & $\begin{array}{l}\text { Blue } \\
\text { Mountain } \\
\text { prospect. }\end{array}$ & $\begin{array}{l}\text { N. } 20^{\circ} \text { W. trending, } 3^{\circ} \mathrm{NE} \text {. } \\
\text { dipping pyrrhotite lense } \\
\text { in argillite. }\end{array}$ & One $8-f t-1$ ong adit & $\begin{array}{l}\text { Three samples assayed no } \\
\text { appreciable metallic } \\
\text { minerals. }\end{array}$ \\
\hline 43 & $\begin{array}{l}\text { Racer } \\
\text { prospect. }\end{array}$ & $\begin{array}{l}\text { Gray metaquartzite } \\
\text { containing traces of pyrite } \\
\text { and chalcopyrite. }\end{array}$ & One 22-ft-long adit & $\begin{array}{l}\text { Two samples: one assayed } \\
0.05 \text { percent copper. }\end{array}$ \\
\hline 44 & $\begin{array}{l}\text { Hidden } \\
\text { Treasure } \\
\text { prospect. }\end{array}$ & $\begin{array}{l}\text { Argillite and quartzite } \\
\text { containing traces of pyrite. }\end{array}$ & $\begin{array}{l}\text { Two adits, } 116 \text { and } \\
8 \mathrm{ft} \text { long. }\end{array}$ & $\begin{array}{l}\text { Five samples assayed no } \\
\text { appreciable metallic } \\
\text { minerals. }\end{array}$ \\
\hline 45 & $\begin{array}{l}\text { Copper } \\
\text { prospect. }\end{array}$ & $\begin{array}{l}\text { N. } 73^{\circ} \text { E. striking, } 77^{\circ} \mathrm{NW} \text {. } \\
\text { dipping shear zone in } \\
\text { cherty argillite. }\end{array}$ & $\begin{array}{l}\text { One } 10-f t-1 \text { ong } \\
\text { opencut. }\end{array}$ & $\begin{array}{l}\text { One sample assayed no } \\
\text { appreciable metallic } \\
\text { minerals. }\end{array}$ \\
\hline
\end{tabular}


Danner, W. R., 1966, Limestone resources of western Washington: Washington Division of Mines and Geology Bulletin 52, 474 p.

Flanigan, V. J., Ford, A. B., and Sherrard, Mark, in press, Interpretation of aeromagnetic survey of Glacier Peak Wilderness, northern Cascades, Washington: U.S. Geological Survey Open-File Report 83-650.

Frizzell, V. A., Jr., Tabor, R. W., Zartman, R. E., and Jones, D. L., 1982, Mesozoic melanges in the western Cascades of Washington abs. : Geological Society of America Abstracts with Programs, v. 14 , no. 4 , p. 164 .

Grant, A. R., 1969, Chemical and physical controls for base metal deposition in the Cascade Range of Washington: Washington Division of Mines and Geology Bulletin 58, 107 p.

Johnson, F. L., Denton, D. K., McCulloch, R. B., and Stebbins, S. A., 1983, Mineral investigations of the Eagle Rock RARE II area (No. 6054), Snohomish and King Counties, Washington: U.S. Bureau of Mines Open-File Report, MLA 54-83, $20 \mathrm{p}$.

Misch, Peter, 1966, Tectonic evolution of the northern Cascade of Washington State--a west cordilleran case history, in Symposium on the tectonic history, mineral deposits of the western cordillera in British Columbia and neighboring parts of the U.S.A.: Canadian Institute of Mining and Metallurgy Special Volume 8, p. 101-148.

1977, Dextral displacements at some major strike faults in the North Cascades abs.: Geological Association of Canada Program with Abstracts, p. 37.

Northwest Mining Journal, June, 1909, Mineral resources of Washington: v. 7, no. 5, p. 54-123.

Pilcher, S. H., and McDougall, J. J., 1976, Characteristics of some Canadian cordilleran porphyry prospects, in Porphyry deposits of the Canadian cordillera: Canadian Institute of Mining Special Volume 15, p. 79-84.

Ream, L. R., 1972, Economic Geology of the Silver Creek mining district, Snohomish County, Washington: Washington State University M.S. thesis, $59 \mathrm{p}$.

Spurr, J. E., 1901, The ore deposits of Monte Cristo, Washington: U.S. Geological Survey Annual Report 22, pt. 2, p. 777-865.

Tabor, R. W., Frizzell, V. A., Jr., Booth, D. B., Whetten, J. T., Waitt, R. B., Jr., and Zartman, R. E., 1982a, Preliminary geologic map of the Skykomish River 1:100,000 quadrangle,
Washington: U.S. Geological Survey Open-File Report 82-747.

Tabor, R. W., Frizzell, V. A., Jr., Yeats, R. S., and Whetten, J. T., 1982b, Geologic map of the Eagle Rock and Glacier Peak Roadless Areas, Snohomish and King Counties, Washington: U.S. Geological Survey Miscellaneous Field Studies Map MF-1380-A, scale 1:100,000.

Toepfer, P. H., 1953, Investigations of the Sunset copper mine, Snohomish County, Washington: U.S. Bureau of Mines Report of Investigations 4989, 9 p.

U.S. Bureau of Mines and U.S. Geological Survey, 1980, Principles of a resource/reserve classification for minerals: U.S. Geological Survey Circular $831,5 \mathrm{p}$.

Vance, J. A., and Miller, R. B., 1981, The movement history of the Straight Creek fault in Washington State, in The last 100 million years (midCretaceaous to Holocene) of geology and mineral deposits in the Canadian Cordillera: Geological Association of Canada, Program and Abstracts for 1981 Meeting, Cordilleran Section, Vancouver, p. 39-41.

Vance, J. A., and Naeser, C. W., 1977, Fission track geochronology of the Tertiary volcanic rocks of the central Cascade Mountains, Washington abs.: Geological Society of America Abstracts with Programs, v. 9, no. 4, 520 p.

Weaver, C. E., 1912, Geology and ore deposits of the Index mining district: Washington Geology Survey Bulletin 7, 93 p.

Whetten, J. T., Zartman, R. E., Blakely, R. J., and Jones, D. L., 1980, Allochthonous Jurassic ophiolite in northwest Washington: Geological Society of America Bulletin, pt. 1, v. 91, p. 359-368.

Yeats, R. S., 1958a, Geology of the Skykomish area in the Cascade Mountains of Washington: Seattle, University of Washington $\mathrm{Ph}$. D. thesis, $249 \mathrm{p}$. $1958 \mathrm{~b}$, Geology of the Skykomish area in the Cascade Mountains of Washington abs. : Dissertation Abstacts, v. 19, no. 4, p. 775. 1964, Crystalline klippen in the Index district, Cascade Range, Washington: Geological Society of America Bulletin, v. 75, p. 549-562.

1977, Structure, stratigraphy, plutonism and volcanism of the central Cascades, Washington, in Brown, E. H., and Ellis, R. C., eds., Geological excursions in the Pacific Northwest: Geological Society of America Field Guide, Annual Meeting, Seattle, p. 265-275. 
